\title{
Several Direct and Calculated Biomarkers from the Amyloid- $\beta$ Pool in Blood are Associated with an Increased Likelihood of Suffering from Mild Cognitive Impairment
}

\author{
Virginia Pérez-Grijalba ${ }^{\mathrm{a}}$, Pedro Pesini ${ }^{\mathrm{a}, \mathrm{b}, *}$, Inmaculada Monleón $^{\mathrm{b}}$, Mercè Boada $^{\mathrm{c}, \mathrm{d}}$, Lluís Tárraga $^{\mathrm{c}}$, \\ Agustín Ruiz-Laza ${ }^{\mathrm{c}}$, Pablo Martínez-Lage ${ }^{\mathrm{c}, 1}$, Itziar San-Joséb and Manuel Sarasa ${ }^{\mathrm{a}, \mathrm{b}}$ \\ ${ }^{\mathrm{a}}$ Araclon Biotech Ltd., Proteomic Laboratory, CIBIR Logroño, Spain \\ ${ }^{\mathrm{b}}$ Araclon Biotech Ltd., I + D Laboratory, Zaragoza, Spain \\ ${ }^{\mathrm{c}}$ Fundació ACE, Institut Català de Neurciències Aplicades, Barcelona, Spain \\ ${ }^{\mathrm{d}}$ Hospital Universitari Vall d'Hebron-Institut de Recerca, Universitat Autònoma de Barcelona (VHIR-UAB), \\ Barcelona, Spain
}

Accepted 3 April 2013

\begin{abstract}
Validation of cost-effective, non-invasive methods to identify early (pre-clinical) Alzheimer's disease (AD) is increasingly becoming a key research challenge. We have developed two ELISA sandwich colorimetric tests for the accurate detection of amyloid- $\beta(\mathrm{A} \beta)_{1-40}$ and $\mathrm{A} \beta_{1-42}$ : i) directly accessible (DA) in the plasma, ii) recovered from the plasma sample (RP) after diluting the plasma sample in a formulated buffer, and iii) associated with the remaining cellular pellet (CP). These tests were carried out on samples from healthy controls $(n=19)$ and individuals with mild cognitive impairment (MCI; $n=27)$ with amnestichippocampal syndrome to investigate whether this comprehensive approach may help to explain the association between blood $\mathrm{A} \beta$ levels and MCI. A logistic regression analysis detected seven direct or calculated markers (CP 40, DA 42, RP 42, DA/CP 40, DA/RP 42, DA/CP 42, and DA 42/40) with significant odds ratios (OR) after they were dichotomized with regard to the median of the pooled population. In particular, the likelihood [OR (95\% CI)] of having MCI for patients with catCP 40, catDA/RP 42, catDA/CP 42, or catDA $42 / 40$ below the corresponding population median ("positive test") was 11.48 (1.87-70.52), 22.09 (3.19-152.61), 11.48 (1.87-70.50), and 9.54 (1.77-51.38)-fold higher, respectively, than in those with a "negative test" after adjusting for the effect of the ApoE genotype. These results are congruent with the hypothesis that changes in blood $A \beta$ levels may be associated with the initial stages of $\mathrm{AD}$. Thus, these $\mathrm{A} \beta$ blood biomarkers might be useful tools for screening for those at increased risk of developing AD.
\end{abstract}

Keywords: Aging, Alzheimer's disease, diagnosis, ELISA

\footnotetext{
${ }^{1}$ Present address: Fundación CITA Alzheimer, San Sebastian, Spain.

*Correspondence to: Pedro Pesini, Araclon Biotech, Frantz Schubert 2, (Hospital Montecanal), 50012 Zaragoza, Spain. Tel.: +34 876241666; Fax: +34 976020011; E-mail: pedropesini@ araclon.com.
}

\section{INTRODUCTION}

Alzheimer's disease (AD) is associated with extracellular deposition of amyloid peptides $(A \beta)$, as well as intracellular accumulation of neurofibrillary tangles. Previously, the presence of amyloid and tau pathology in autopsied brains from cognitively healthy people was thought to refute the amyloid cascade hypothesis. 
Currently, however, these findings are interpreted as proof of the preclinical course of the disease and indicate that $\mathrm{AD}$ pathology is active and detectable many years before manifestation of overt dementia [1-7]. This interpretation of AD's natural history has driven recent research efforts toward developing earlier-course and preventive treatments and the search for surrogate diagnostic biomarkers [8].

In line with this interpretation, the work carried out in large multicenter initiatives such as the Alzheimer's Disease Neuroimaging Initiative (ADNI), the Australian Imaging Biomarkers and lifestyle Flagship Study of Ageing (AIBL), European-ADNI (E-ADNI), and many others has led to the proposal of a model in which the most widely validated biomarkers (MRI, PIB-PET, FDG-PET, and CSF levels of A $\beta$, tau, and phosphorylated-tau) become abnormal in an ordered sequence that parallels the hypothetical pathophysiological sequence of AD $[9,10]$.

However, these well-validated biomarkers are hampered by practical pitfalls that severely limit their application in large populations. The feasibility of these biomarkers for screening the general population once a preventive treatment has been developed also remains questionable. Consequently, there is an increasing interest in the development of blood-based biomarkers among which $\mathrm{A} \beta$ peptides have attracted particular attention because of their proven mechanistic relationship with $\mathrm{AD}$ pathology and accumulating evidence that changes in brain $A \beta$ are among the first detectable signs of disease onset [6,11-17].

Our hypothesis is that changes in blood $A \beta$ levels may reflect changes in brain $A \beta$ levels due to an amyloid cortical pathology that heralds AD. Indeed, the majority of previous cross-sectional studies showed statistically significant associations between $A \beta$ plasma markers (primarily $A \beta_{40}, A \beta_{42}$, or the $\mathrm{A} \beta_{42} / \mathrm{A} \beta_{40}$ ratio) and a determined diagnosis [healthy control (HC), mild cognitive impairment (MCI) or AD] [18-31]. However, the details of this association remain far from clear and the literature has produced controversial results (for a recent review, see [32]).

There are numerous confounding factors from a variety of sources that blur the presumptive association of $\mathrm{A} \beta$ blood levels and the diagnosis of $\mathrm{AD}$. These include technical issues, the long pre-clinical course of the disease, and the variable patient history of the elderly, which can affect the metabolism of $A \beta$ in different ways [33]. The interaction of all (or several) of these confounding factors could lead to conflicting-even entirely opposite-results coming from different studies.
Another relevant source of confusion is the fragmentary knowledge of the biology of $A \beta$ in the blood. An important point to be stressed is that $A \beta$ peptides in blood can be found free in the plasma, bound to plasma proteins, and bound to blood cells [34-39]. Therefore, a complete $A \beta$ blood test should include the determination of peptide levels in each of these three fractions. Our study represents a first step in this direction and an attempt to gain as much information as possible regarding the distribution of these peptides in the blood. To these ends, we separately assessed the peptide directly accessible in the plasma, the peptide that can be recovered after diluting the plasma sample in a formulated buffer, and the peptide that remains adhered to the cellular pellet after plasma collection.

The aim of the present study was to investigate whether this comprehensive approach could help explain the association between blood $A \beta$ levels and the early stages of AD.

\section{MATERIAL AND METHODS}

The demographic characteristics of the participants are summarized in Table 1. The HC $(n=19)$ and MCI $(n=27)$ diagnostic groups were established according to the routines of the Memory Clinic of Fundació ACE as described elsewhere [40]. The MCI patients fulfilled the Mayo Clinic criteria with a clinical dementia ratio (CDR) of 0.5 and a normal MMSE. The patients were described as amnesic with hippocampal syndrome based on the Wechsler Memory Scale-III (WMS-III) as described elsewhere [41]. The MCI group was subdivided into those with a negative neuroimage (MCI-NIn; $n=12$ ) suggestive of an earlier disease stage and those with a positive neuroimage (MCI-NIp; $n=15$ ) suggestive of a more advanced disease stage. To be classified as MCI-NIn, patients should present $<4$ points bilaterally on the Scheltens scale for medial temporal atrophy, as assessed using MRI, and no signs of hypometabolism in the medial temporal or cingular posterior region, as assessed using FDGPET. To be classified as MCI-NIp, patients present $\geq 4$ points bilaterally on the Scheltens scale and/or signs of hypometabolism in the medial temporal or cingular posterior regions [42].

Written informed consent was obtained from every participant. The study protocols were reviewed and approved by the Ethical Committee of the Hospital Clínic i Provincial (Barcelona, Spain). Education level was recorded in five categories depending on the number of years of education. However, cases had to be 
Table 1

Demographic characteristics of the participants

\begin{tabular}{lccccc}
\hline Groups & $n$ & Age $($ mean \pm SD) & Gender (female/male) & APOE $\varepsilon 4$ carriers & Education level $\leq 8$ years \\
\hline HC versus MCI & & $p=0.004$ & $p=0.116$ & $P<0.001$ & $1(5.3 \%)$ \\
HC & 19 & $69.53 \pm 4.20$ & $9 / 10$ & $17(63.0 \%)$ & $2(10.5 \%)$ \\
MCI & 27 & $74.30 \pm 6.26$ & $19 / 8$ & $p=0.722$ & $16(59.3 \%)$ \\
NIn versus NIp & & $p=0.201$ & $p=0.637$ & $8(66.67 \%)$ & $8=0.484$ \\
MCI-NIn & 12 & $72.81 \pm 6.74$ & $9 / 3$ & $9(60.0 \%)$ & $8(53.3 \%)$ \\
MCI-NIp & 15 & $75.49 \pm 5.79$ & $10 / 5$ & \\
\hline
\end{tabular}

HC, healthy control; MCI, mild cognitive impairment; MCI-Nin, MCI group with a negative neuroimage; MCI-Nip, MCI group with a positive neuroimage.

regrouped into two categories (more or less than 8 years of education) to fulfill the lowest expected frequency condition in the contingency table.

\section{Blood sampling and biochemical determinations}

Blood samples from each participant were drawn in the morning after an overnight fast and were collected in polypropylene vials with EDTA and a protease inhibitor cocktail (Complete Mini, Roche Madrid Spain). The samples were immediately cooled to $4^{\circ} \mathrm{C}$ until processing which occurred in the first 24 hours after collection. The blood samples were centrifuged and both the plasma and the cell pellet were divided into aliquots and stored in polypropylene tubes at $-80^{\circ} \mathrm{C}$ until analyzed. At no time was the material thawed or refrozen.

All samples were analyzed in triplicate in the same run for each of the three blood fractions using two specific ELISA sandwich kits, ABtest 40 and ABtest 42 (Araclon Biotech Ltd. Zaragoza, Spain), as described elsewhere [30]. Before analysis, plasma and blood cell samples were pretreated using dilution in a formulated saline buffer with $1 \%$ blocking polymer according to the supplier's instructions.

We carried out three counts for both the $A \beta_{40}$ and $A \beta_{42}$ peptides in each blood sample. One count was performed using the undiluted plasma sample, another using the plasma sample diluted 1:3 with the aforementioned formulated buffer, and a third using the cellular pellet that remained after plasma collection. The peptide amount in the undiluted plasma sample corresponds to the directly accessible (DA) peptide. The 1:3 dilution of the plasma was chosen because it provided the maximum peptide recovery from the sample (see Supplementary Figure 1; available online: http://dx.doi.org/10.3233/JAD-121744). Thus, this count included the DA peptide and the peptide that was recovered from the plasma matrix (RP). Additionally, the peptide associated with the cellular pellet $(\mathrm{CP})$ was measured in a 1:5 dilution of the pellet that remained after plasma collection. The sum of these three amounts is described as the $A \beta$ pool in blood (PIB) for either $A \beta_{40}$ or $A \beta_{42}$. Additionally, from these directly measured markers, we obtain the ratios of DA/RP, DA/CP, and RP/CP for each peptide and the ratios of DA $A \beta_{42}$ to DA A $\beta_{40}$ (DA42/40), RP $\mathrm{A} \beta_{42}$ to RP A $\beta_{40}$ (RP42/40), and CP A $\beta_{42}$ to $C P A \beta_{40}$ (CP42/40) (see Table 2).

The inter-assay coefficients of variation (CV), as determined by the comparison of the same plasma control samples measured in the assay for either the diluted plasma, undiluted plasma or cells were $4.94 \%$ and $11.11 \%$ in ABtest40 and ABtest 42 , respectively. The limit of quantification (LQ) was $4.70 \mathrm{pg} / \mathrm{ml}$ for ABtest40 and $5.71 \mathrm{pg} / \mathrm{ml}$ for ABtest 42 . None of the

Table 2

Direct and calculated $\mathrm{A} \beta$ blood markers

\begin{tabular}{|c|c|c|c|c|c|c|}
\hline & DA 40 & RP 40 & CB 40* & DA $42 *$ & $\mathrm{RP} 42 *$ & CB 42 \\
\hline$\overline{\mathrm{HC}}$ & $55.58(14.62)$ & $30.56(7.06)$ & $61.47(87.64)$ & $12.72(3.92)$ & $21.98(9.07)$ & $\overline{102.57(58.31)}$ \\
\hline \multirow[t]{2}{*}{$\mathrm{MCI}$} & $56.95(18.08)$ & $34.17(18.46)$ & $56.11(14.71)$ & $9.14(7.74)$ & $32.20(21.48)$ & $168.67(109.87)$ \\
\hline & DA/RP 40 & DA/CB $40^{*}$ & $\mathrm{RP} / \mathrm{CB} 40$ & DA/RP $42 * * *$ & $\mathrm{DA} / \mathrm{CB} 42 * *$ & $\mathrm{RP} / \mathrm{CB} 42$ \\
\hline$\overline{\mathrm{HC}}$ & $1.72(0.76)$ & $0.84(0.24)$ & $0.50(0.14)$ & $0.50(0.31)$ & $0.11(0.05)$ & $0.22(0.16)$ \\
\hline \multirow[t]{2}{*}{$\underline{\mathrm{MCI}}$} & $1.55(1.59)$ & $0.96(0.36)$ & $0.64(0.37)$ & $0.26(0.21)$ & $0.06(0.07)$ & $0.20(0.21)$ \\
\hline & DA $42 / 40 * *$ & RP 42/40* & $\mathrm{CP} 42 / 40^{*}$ & PIB 40 & PIB 42 & PIB $40+42$ \\
\hline $\mathrm{HC}$ & $0.21(0.06)$ & $0.79(0.30)$ & $1.62(0.98)$ & $146.22(12.68)$ & $151.21(66.22)$ & $298.31(62.57)$ \\
\hline MCI & $0.15(0.09)$ & $0.99(0.74)$ & $2.89(2.23)$ & $151.41(29.47)$ & 206.03 (126.69) & $357.43(149.88)$ \\
\hline
\end{tabular}

Data [median (interquartile range)] are in pg/mL. ${ }^{*} p<0.05 ; * * p<0.01 ; * * *<0.001$ in HC versus MCI groups. 
determinations for ABtest40 was under its LQ, but $13 \%$ of the determinations of DA $A \beta_{42}$ (although detectable) were under the LQ of ABtest42.

APOE genotyping was performed as previously described [43], using the amplification of genomic DNA, digestion with HhaI, and further analysis of the restriction fragments.

\section{Statistical analysis}

To compare demographic data between the two groups, we ran a Mann-Whitney U-test for continuous variables. Pearson's chi-square test was used for the categorical variables. Binary logistic regression was performed to assess whether the level of chosen markers (split in two by the median of the pooled population) were associated with an increased likelihood of an MCI diagnosis in an unadjusted model and in models adjusted for age, ApoE genotype, or education level. Regarding their distribution within a group, only the markers with a $p$ value $<0.05$ (MannWhitney test) were analyzed using logistic regression. Four individuals had outlier values for some of the markers, and $13 \%$ (six individuals) of the DA A $\beta_{42}$ measurements were below the LQ. Because the primary results were obtained from the logistic regression analyses of dichotomous variables, the influenced of these extreme data was considered irrelevant and they were not excluded from the study. Sensitivity and specificity of the $A \beta_{40}$ and $A \beta_{42}$ blood biomarkers with a significant $\mathrm{OR}$ were calculated by determining the most appropriate cutoff from their corresponding receiver operating characteristic (ROC) curve. The correlation between the $\mathrm{A} \beta$ markers and the hematological and blood biochemical variables was explored using a Spearman test. The SPSS v.20 software was used for statistical analysis. Graphics and figures were created using Graph Pad Prism v5.0.

\section{RESULTS}

The two primary diagnostic groups (HC and MCI) differed significantly depending on age, presence of ApoE $\varepsilon 4$, and education level (Table 1). By contrast, the two MCI subgroups (MCI-NIn and MCI-NIp) were completely homogeneous regarding those variables.

A group comparison revealed that nine direct and calculated markers differed significantly between $\mathrm{HC}$ and MCI (Table 2). Interestingly, whereas the levels of DA 42 were lower in MCI than in HC, the levels of RP 42 and CP 42 were lower in HC than in MCI (Fig. 1). The most significant results in the comparison between
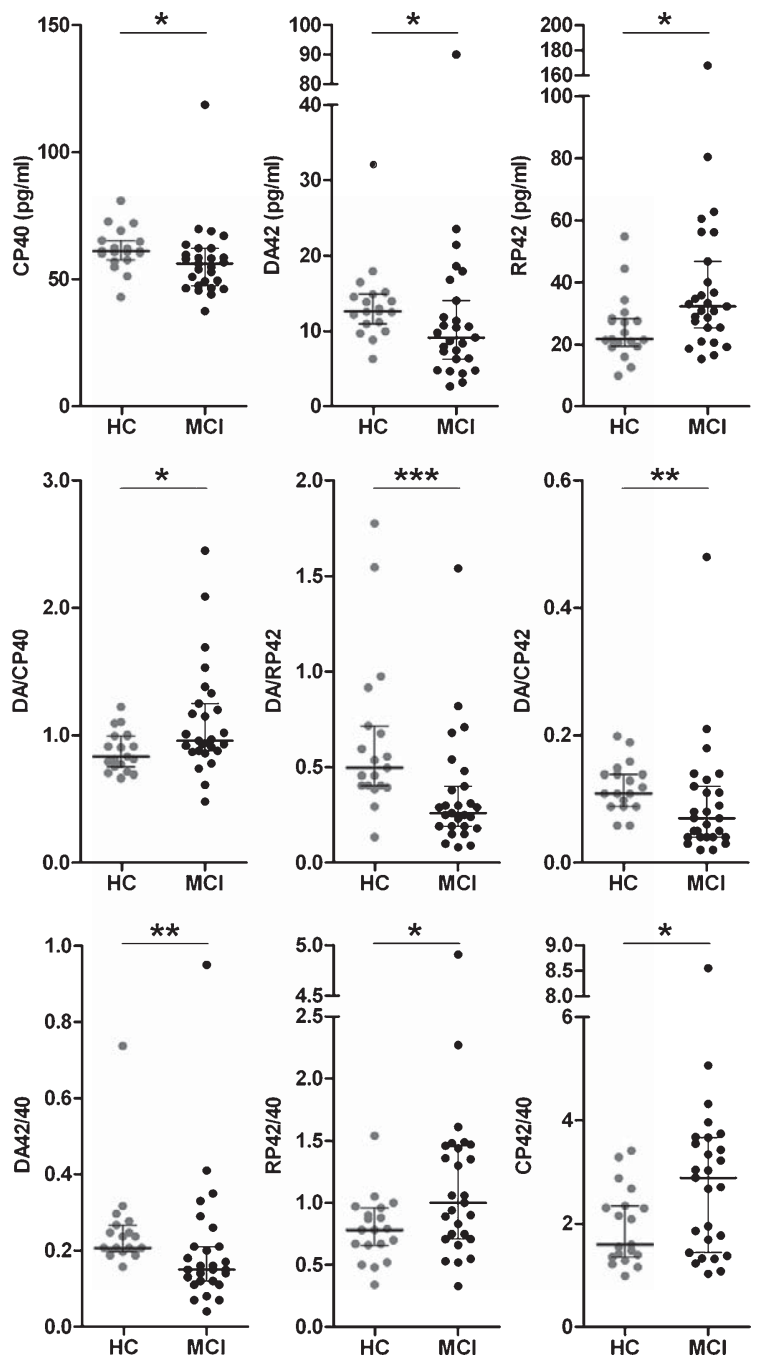

Fig. 1. Dot plot graphs of the direct and calculated markers that reached statistically significant differences between healthy controls (HC) and mild cognitive impairment (MCI) patients. ${ }^{*} * *<0.001$, $* * p<0.01$, and $* p<0.05$.

$\mathrm{HC}$ and $\mathrm{MCI}$ were the DA/RP 42 ratio followed by the DA/CP 42 and DA 42/40 ratios, which were $48 \%, 45 \%$, and $28 \%$ lower in the MCI group than in the HC group, respectively.

Additionally, seven of those nine markers (CP 40, DA 42, RP 42, DA/RP 42, DA/CP 42, DA 42/40 and RP 42/40) were found to differ significantly ( $p$ value equals $0.014,0.008,0.002,<0.001,0.025,0.001$, 0.001 , respectively) when the MCI-NIn group was compared with the HC group. By contrast, no marker displayed significant differences between the two MCI subgroups (MCI-NIn versus MCI-NIp).

The binary logistic regression analysis showed that, once transformed in categorical (cat) variables that 
Table 3

Odd ratios for the selected blood markers dichotomized by the median of the pooled population sample

\begin{tabular}{|c|c|c|c|c|c|c|c|c|c|c|c|c|}
\hline \multirow{3}{*}{$\begin{array}{l}\text { MCI versus HC } \\
\text { catCP } 40^{\S}\end{array}$} & \multicolumn{3}{|c|}{ unadjusted } & \multicolumn{3}{|c|}{ adjusted for age } & \multicolumn{3}{|c|}{$\begin{array}{c}\text { adjusted for ApoE } \\
\text { genotype }\end{array}$} & \multicolumn{3}{|c|}{$\begin{array}{c}\text { adjusted for education } \\
\text { level }\end{array}$} \\
\hline & \multirow{2}{*}{$\begin{array}{c}\mathrm{OR} \\
5.60 * *\end{array}$} & \multicolumn{2}{|c|}{$95 \% \mathrm{CI}$} & \multirow{2}{*}{$\frac{\mathrm{OR}}{5.19 *}$} & \multicolumn{2}{|c|}{$95 \% \mathrm{CI}$} & \multirow{2}{*}{$\frac{\mathrm{OR}}{11.48 * *}$} & \multicolumn{2}{|c|}{$95 \% \mathrm{CI}$} & \multirow{2}{*}{$\frac{\mathrm{OR}}{5.90^{*}}$} & \multicolumn{2}{|c|}{$95 \% \mathrm{CI}$} \\
\hline & & 1.53 & 20.49 & & 1.27 & 21.20 & & 1.87 & 70.50 & & 1.32 & 26.28 \\
\hline catDA $42^{\S}$ & $5.60 * *$ & 1.53 & 20.49 & $10.12 * *$ & 1.91 & 53.55 & 3.52 & 0.77 & 16.11 & $5.90 *$ & 1.32 & 26.28 \\
\hline catRP $42^{\S}$ & $5.60 * *$ & 1.53 & 20.49 & $15.31 * *$ & 2.44 & 96.04 & $11.48 * *$ & 1.87 & 70.50 & 2.47 & 0.55 & 11.02 \\
\hline catDA/CP 40 & $3.68 *$ & 1.06 & 12.77 & 2.57 & 0.67 & 9.81 & $5.41 *$ & 1.08 & 27.00 & 3.42 & 0.83 & 14.03 \\
\hline catDA/RP $42^{\S}$ & $15.23 * * *$ & 3.38 & 68.55 & $669.88 * *$ & 7.81 & 57434.87 & $22.09 * *$ & 3.19 & 152.61 & $9.75 * *$ & 1.97 & 48.06 \\
\hline catDA/CP $42^{\S}$ & $5.60 * *$ & 1.53 & 20.49 & $7.21 * *$ & 1.61 & 32.36 & $11.48 * *$ & 1.87 & 70.50 & $8.15^{* *}$ & 1.66 & 39.98 \\
\hline catDA $42 / 40^{\S}$ & $8.90^{* *}$ & 2.24 & 35.33 & $11.88 * *$ & 2.34 & 60.30 & $9.54 * *$ & 1.77 & 51.38 & $8.13^{* *}$ & 1.74 & 38.02 \\
\hline catRP $42 / 40$ & 2.49 & 0.74 & 8.34 & 2.79 & 0.72 & 10.67 & 2.89 & 0.64 & 13.01 & 1.65 & 0.41 & 6.53 \\
\hline catCP $42 / 40$ & 2.00 & 0.60 & 6.58 & 2.27 & 0.60 & 8.62 & 3.45 & 0.71 & 16.66 & 1.70 & 0.43 & 6.62 \\
\hline
\end{tabular}

§indicates test positive if marker's level was equal or below the population median. $* p<0.05 ; * * p<0.01, * * * p<0.001$.

Table 4

Sensitivity and specificity of selected markers

\begin{tabular}{lcccc}
\hline HC versus MCI & $\begin{array}{c}\text { Cutoff. } \\
\text { Test }+ \text { if }\end{array}$ & Sensitivity & Specificity & AUC \\
\hline CP 40 & $<59.983$ & 0.737 & 0.741 & $0.717^{*}$ \\
DA 42 & $<10.891$ & 0.789 & 0.667 & $0.704 *$ \\
RP 42 & $>30.607$ & 0.593 & 0.842 & $0.712^{*}$ \\
DA/CP 40 & $>0.852$ & 0.852 & 0.526 & $0.692^{*}$ \\
DA/RP 42 & $<0.384$ & 0.895 & 0.741 & $0.801 * *$ \\
DA/CP 42 & $<0.082$ & 0.895 & 0.630 & $0.743^{*} *$ \\
DA 42/40 & $<0.176$ & 0.947 & 0.630 & $0.754 *$ \\
\hline
\end{tabular}

AUC area under the ROC curve. ${ }^{*} p<0.05,{ }^{*} * p<0.01$.

split the population in two at the median, seven of the nine aforementioned markers differed significantly between $\mathrm{HC}$ and $\mathrm{MCI}$ and presented significant ORs (Table 3). Furthermore, catCP 40, catDA/RP 42, catDA/CP 42 and catDA 42/40 maintained a significant OR when each demographic co-variable was compensated for. Thus, the likelihood of being an MCI case for those patients having catCP 40, catDA/RP 42, catDA/CP 42, or catDA 42/40 below the corresponding population median ("positive test") was $11.48,22.09$, 11.48, and 9.54-fold higher, respectively, than in those with a "negative test" after adjusting for the effect of the ApoE genotype (Table 4).

The sensitivity and specificity of these selected markers were tentatively assessed using their corresponding ROC curves (Table 4). In particular, the area under the curve (AUC) was 0.80 for catDA/RP 42, 0.74 for catDA/CP 42, and 0.75 for catDA 42/40, which are acceptable but not impressive values.

Direct $A \beta$ markers did not generally show a consistent correlation pattern with the hematological and blood biochemical variables (see Supplementary Table 1). More significant correlations occurred between CP 42 and serum albumin $(r=-407$, $p=0.005)$ and between DA 40 and creatinine $(r=0.615, p<0.001)$. Interestingly, DA 40 also showed a significant negative correlation with hematocrit $(r=-0.351, p=0.017)$ and homocysteine $(r=0.344$, $p=0.019)$.

\section{DISCUSSION}

In the present work, we found nine markers from the $\mathrm{A} \beta$ pool in blood that differed significantly between a group of MCI patients of the amnestic-hippocampic type and a HC group. Once they were transformed in categorical variables, four of these markers (CP 40, DA/RP 42, DA/CP 42, and DA 42/40), presented significant ORs even when the logistic regression model was adjusted for each of the relevant demographic covariables. The results showed an association beyond what could be attributable to pure chance between these $\mathrm{A} \beta$ blood markers and an MCI diagnosis. However, the significance of this association remains controversial, and there is a wealth of literature showing contradictory results (for recent reviews, see $[28,32,44])$. Nevertheless, apart from other relevant markers, our study revealed that levels of DA 42 and the ratio of DA 42/40 were lower in the MCI group than in the HC group, which is congruent with numerous previous reports [18, 23, 25, 26, 28, 29, 45-48]. Furthermore, whereas DA 42 was lower in MCI than in $\mathrm{HC}$, levels of RP 42 trended in the opposite direction. This finding could help to explain the variability of results obtained with the different assays used in various studies. It is well known that $\mathrm{A} \beta$ peptides bind to plasma proteins and blood cells in amounts that depend on various factors that may or may not be related to $\mathrm{AD}$ pathology [34-38, 49-52]. Depending on the ability of a given assay to measure jointly the levels of peptide free in the plasma and a variable proportion of the $A \beta$ peptides bound to plasma proteins, a single $A \beta$ plasma measurement would fluctuate in one or other direction. 
Concerning this point, our results suggest that separately quantifying the levels of $\mathrm{A} \beta$ peptides directly accessible in the plasma, the levels recovered from masking interactions with the plasma matrix and the levels associated to the cellular pellet could lead to a more comprehensive assessment of $\mathrm{A} \beta$ levels in blood (not just in plasma) and their relative distribution among these three blood compartments, improving the diagnostic ability of the $A \beta$ blood test. In line with this, five of the seven markers that we have found associated with increased likelihood of being MCI and, in particular, two out of the three with the highest OR (i.e., $\mathrm{DA} / \mathrm{RP} 42$, DA/CP 42) included $\mathrm{A} \beta$ measurements other than those of free peptide levels in the plasma. These findings suggest that there is a clear necessity for a better understanding of the biology and dynamic interactions between $A \beta$ peptides and the complex proteome matrix of the plasma. This knowledge would lead to optimization and standardization of protocols that would improve reproducibility of the assays and facilitate comparison of results from between different laboratories [33]. Nevertheless, we believe that both the relatively wide range of the individual measurements within a given group and the considerable overlapping values between groups, indicate that the highest diagnostic value of a given $\mathrm{A} \beta$ blood marker could be more directly related to its rate of change over the time than to its level at a given moment [8].

All the MCI patients in the present study were clinically characterized as having MCI of the amnestic/hippocampic type known to have a high rate of conversion to $\mathrm{AD}[17,53,54]$. Based on published data, those with a positive MRI and/or an FDG-PET neuroimage (MCI-NIp) may be considered to be at a more advanced stage of the disease than those with negative neuroimage biomarkers (MCI-NIn) [6, 15, 16, 55-57]. Interestingly, CP 40, DA 42, RP 42, DA/RP 42, DA/CP 42, DA 42/40, and RP 42/40 (seven of the nine $\mathrm{A} \beta$ blood biomarkers that differentiated $\mathrm{HC}$ from MCI) were also found to significantly differentiate between HC and MCI-NIn. By contrast, no single $\mathrm{A} \beta$ blood marker was found to be significantly different between two subgroups of MCI patients when compared with each other (data not shown). These results are congruent with the idea that changes in brain $A \beta$ are among the earliest detectable signs in the course of $\mathrm{AD}$, reaching a plateau at the MCI stage and before the manifestation of overt clinical symptoms $[9,58,59]$. Whether this is the case for blood $A \beta$ peptides remains to be proven. However, recent reports have provided promising results in this direction. For example, Toledo et al. [26] described a modest but sig- nificant correlation between plasma and CSF $A \beta_{1-42}$ levels in a sample of 715 ADNI subjects (205 HC, $348 \mathrm{MCI}$, and $162 \mathrm{AD}$ ). This correlation was slightly better between plasma $A \beta_{1-42}$ levels and brain amyloid deposits, thereby confirming results from other studies $[60,61]$. Recently, other authors have reported correlations between levels of $A \beta_{1-40}$ and $A \beta_{1-42}$ free in plasma with the CSF tau/A $\beta_{1-42}$ ratio [38]. Interestingly, a recent publication from the Dominantly Inherited Alzheimer Network (DIAN) has shown that plasma $A \beta_{1-42}$ levels are significantly higher in carriers of mutations for autosomal dominant AD than in non-carriers five years before such differences reach statistical significance in $A \beta_{1-42}$ CSF levels [62].

Taken together, these results have boosted the interest in blood-based biomarkers and both $A \beta_{1-40}$ and $A \beta_{1-42}$ are increasingly considered moderate risk markers for AD well suited to be used as pharmacodynamic markers and eventually as a minimally invasive screen to identify people at increased risk of developing AD. Ongoing longitudinal studies may validate these results and confirm these hypotheses.

\section{ACKNOWLEDGMENTS}

This work was financed by Araclon Biotech Ltd. The authors express their gratitude to Dr. Ignacio de Blas for his revisions and his advice regarding the statistical procedures.

Authors' disclosures available online (http://www.jalz.com/disclosures/view.php?id=1736).

\section{SUPPLEMENTARY MATERIAL}

Supplementary material can be found here: http:// dx.doi.org/10.3233/JAD-121744

\section{REFERENCES}

[1] Nelson PT, Braak H, Markesbery WR (2009) Neuropathology and cognitive impairment in Alzheimer disease: A complex but coherent relationship. J Neuropathol Exp Neurol 68, 1-14.

[2] Fagan AM, Holtzman DM (2010) Cerebrospinal fluid biomarkers of Alzheimer's disease. Biomark Med 4, 51-63.

[3] Sperling RA, Aisen PS, Beckett LA, Bennett DA, Craft S, Fagan AM, Iwatsubo T, Jack CR, Kaye J, Montine TJ, Park DC, Reiman EM, Rowe CC, Siemers E, Stern Y, Yaffe K, Carrillo MC, Thies B, Morrison-Bogorad M, Wagster MV, Phelps CH (2011) Toward defining the preclinical stages of Alzheimer's disease: Recommendations from the National Institute on Aging and the Alzheimer's Association workgroup. Alzheimers Dement 7, 280-292.

[4] Aisen PS (2009) Alzheimer's disease therapeutic research: The path forward. Alzheimers Res Ther 1, 2. 
[5] Vellas B, Aisen PS, Sampaio C, Carrillo M, Scheltens P, Scherrer B, Frisoni GB, Weiner M, Schneider L, Gauthier S, Wied CC, Hendrix S, Feldman H, Cedarbaum J, Petersen R, Siemers E, Andrieu S, Prvulovic D, Touchon J, Hampel H (2011) Prevention trials in Alzheimer's disease: An EU-US task force report. Prog Neurobiol 95, 594-600.

[6] Ewers M, Insel P, Jagust WJ, Shaw L, Trojanowski JJ, Aisen P, Petersen RC, Schuff N, Weiner MW (2012) CSF biomarker and PIB-PET-derived beta-amyloid signature predicts metabolic, gray matter, and cognitive changes in nondemented subjects. Cereb Cortex 22, 1993-2004.

[7] Villemagne VL, Pike KE, Chetelat G, Ellis KA, Mulligan RS, Bourgeat P, Ackermann U, Jones G, Szoeke C, Salvado O, Martins R, O'Keefe G, Mathis CA, Klunk WE, Ames D, Masters CL, Rowe CC (2011) Longitudinal assessment of Abeta and cognition in aging and Alzheimer disease. Ann Neurol 69, 181-192.

[8] Hampel H, Lista S, Khachaturian ZS (2012) Development of biomarkers to chart all Alzheimer's disease stages: The royal road to cutting the therapeutic Gordian Knot. Alzheimers Dement 8, 312-336.

[9] Jack CR, Jr., Knopman DS, Jagust WJ, Shaw LM, Aisen PS, Weiner MW, Petersen RC, Trojanowski JQ (2010) Hypothetical model of dynamic biomarkers of the Alzheimer's pathological cascade. Lancet Neurol 9, 119-128.

[10] Jack CR, Jr., Vemuri P, Wiste HJ, Weigand SD, Aisen PS, Trojanowski JQ, Shaw LM, Bernstein MA, Petersen RC, Weiner MW, Knopman DS (2011) Evidence for ordering of Alzheimer disease biomarkers. Arch Neurol 68, 15261535.

[11] Shaw LM, Vanderstichele H, Knapik-Czajka M, Clark CM, Aisen PS, Petersen RC, Blennow K, Soares H, Simon A, Lewczuk P, Dean R, Siemers E, Potter W, Lee VM, Trojanowski JQ (2009) Cerebrospinal fluid biomarker signature in Alzheimer's disease neuroimaging initiative subjects. Ann Neurol 65, 403-413.

[12] Fagan AM, Roe CM, Xiong C, Mintun MA, Morris JC, Holtzman DM (2007) Cerebrospinal fluid tau/beta-amyloid(42) ratio as a prediction of cognitive decline in nondemented older adults. Arch Neurol 64, 343-349.

[13] Stomrud E, Hansson O, Zetterberg H, Blennow K, Minthon L, Londos E (2010) Correlation of longitudinal cerebrospinal fluid biomarkers with cognitive decline in healthy older adults. Arch Neurol 67, 217-223.

[14] Rolstad S, Berg AI, Bjerke M, Blennow K, Johansson B, Zetterberg H, Wallin A (2011) Amyloid-beta is associated with cognitive impairment in healthy elderly and subjective cognitive impairment. J Alzheimers Dis 26, 135-142.

[15] Fagan AM, Mintun MA, Mach RH, Lee SY, Dence CS, Shah AR, LaRossa GN, Spinner ML, Klunk WE, Mathis CA, DeKosky ST, Morris JC, Holtzman DM (2006) Inverse relation between in vivo amyloid imaging load and cerebrospinal fluid Abeta42 in humans. Ann Neurol 59, 512-519.

[16] Rowe CC, Ellis KA, Rimajova M, Bourgeat P, Pike KE, Jones G, Fripp J, Tochon-Danguy H, Morandeau L, O'Keefe G, Price R, Raniga P, Robins P, Acosta O, Lenzo N, Szoeke C, Salvado O, Head R, Martins R, Masters CL, Ames D, Villemagne VL (2010) Amyloid imaging results from the Australian Imaging, Biomarkers and Lifestyle (AIBL) study of aging. Neurobiol Aging 31, 1275-1283.

[17] Buchhave P, Minthon L, Zetterberg H, Wallin AK, Blennow K, Hansson O (2012) Cerebrospinal fluid levels of betaAmyloid 1-42, but not of Tau, are fully changed already 5 to 10 years before the onset of Alzheimer dementia. Arch Gen Psychiatry 69, 98-106.
[18] Graff-Radford NR, Crook JE, Lucas J, Boeve BF, Knopman DS, Ivnik RJ, Smith GE, Younkin LH, Petersen RC, Younkin SG (2007) Association of low plasma Abeta42/Abeta40 ratios with increased imminent risk for mild cognitive impairment and Alzheimer disease. Arch Neurol 64, 354-362.

[19] Schupf N, Tang MX, Fukuyama H, Manly J, Andrews H, Mehta P, Ravetch J, Mayeux R (2008) Peripheral A $\beta$ subspecies as risk biomarkers of Alzheimer's disease. Proc Natl Acad Sci U S A 105, 14052-14057.

[20] Blasko I, Jellinger K, Kemmler G, Krampla W, Jungwirth S, Wichart I, Tragl KH, Fischer P (2008) Conversion from cognitive health to mild cognitive impairment and Alzheimer's disease: Prediction by plasma amyloid beta 42, medial temporal lobe atrophy and homocysteine. Neurobiol Aging 29, $1-11$.

[21] Mehta PD, Pirttila T, Mehta SP, Sersen EA, Aisen PS, Wisniewski HM (2000) Plasma and cerebrospinal fluid levels of amyloid beta proteins 1-40 and 1-42 in Alzheimer disease. Arch Neurol 57, 100-105.

[22] Mayeux R, Honig LS, Tang MX, Manly J, Stern Y, Schupf N, Mehta PD (2003) Plasma A $\beta 40$ and A $\beta 42$ and Alzheimer's disease: Relation to age, mortality, and risk. Neurology 61, 1185-1190.

[23] Sundelof J, Giedraitis V, Irizarry MC, Sundstrom J, Ingelsson E, Ronnemaa E, Arnlov J, Gunnarsson MD, Hyman BT, Basun H, Ingelsson M, Lannfelt L, Kilander L (2008) Plasma beta amyloid and the risk of Alzheimer disease and dementia in elderly men: A prospective, population-based cohort study. Arch Neurol 65, 256-263.

[24] Schupf N, Patel B, Pang D, Zigman WB, Silverman W, Mehta PD, Mayeux R (2007) Elevated plasma beta-amyloid peptide Abeta(42) levels, incident dementia, and mortality in Down syndrome. Arch Neurol 64, 1007-1013.

[25] Yaffe K, Weston A, Graff-Radford NR, Satterfield S, Simonsick EM, Younkin SG, Younkin LH, Kuller L, Ayonayon HN, Ding J, Harris TB (2011) Association of plasma beta-amyloid level and cognitive reserve with subsequent cognitive decline. JAMA 305, 261-266.

[26] Toledo JB, Vanderstichele H, Figurski M, Aisen PS, Petersen RC, Weiner MW, Jack CR, Jr., Jagust W, Decarli C, Toga AW, Toledo E, Xie SX, Lee VM, Trojanowski JQ, Shaw LM (2011) Factors affecting Abeta plasma levels and their utility as biomarkers in ADNI. Acta Neuropathol 122, 401413.

[27] Hansson O, Stomrud E, Vanmechelen E, Ostling S, Gustafson DR, Zetterberg H, Blennow K, Skoog I (2012) Evaluation of plasma Abeta as predictor of Alzheimer's disease in older individuals without dementia: A population-based study. $J$ Alzheimers Dis 28, 231-238.

[28] Koyama A, Okereke OI, Yang T, Blacker D, Selkoe DJ, Grodstein F (2012) Plasma amyloid-beta as a predictor of dementia and cognitive decline: A systematic review and meta-analysis. Arch Neurol 69, 824-831.

[29] Lui JK, Laws SM, Li QX, Villemagne VL, Ames D, Brown B, Bush AI, De RK, Dromey J, Ellis KA, Faux NG, Foster J, Fowler C, Gupta V, Hudson P, Laughton K, Masters CL, Pertile K, Rembach A, Rimajova M, Rodrigues M, Rowe CC, Rumble R, Szoeke C, Taddei K, Taddei T, Trounson B, Ward V, Martins RN, AIBL Research Group (2010) Plasma amyloid-beta as a biomarker in Alzheimer's disease: The AIBL study of aging. J Alzheimers Dis 20, 1233-1242.

[30] Pesini P, Pérez-Grijalva V, Monleón I, Boada M, Tárraga L, Martínez-Lage P, San-José I, Sarasa M (2012) Reliable measurements of the $\beta$-amyloid pool in blood could help in the early diagnosis of AD. Int J Alzheimers Dis 2012, 604141. 
[31] Gabelle A, Richard F, Gutierrez LA, Schraen S, Delva F, Rouaud O, Buee L, Dartigues JF, Touchon J, Lambert JC, Berr C (2013) Plasma amyloid-beta levels and prognosis in incident dementia cases of the 3-City study. J Alzheimers Dis 33, 381-391.

[32] Watt AD, Perez KA, Rembach AR, Masters CL, Villemagne VL, Barnham KJ (2012) Variability in blood-based amyloidbeta assays: The need for consensus on pre-analytical processing. J Alzheimers Dis 30, 323-326.

[33] Lista S, Faltraco F, Hampel H (2013) Biological and methodical challenges of blood-based proteomics in the field of neurological research. Prog Neurobiol 101-102 18-34.

[34] Rogers J, Li R, Mastroeni D, Grover A, Leonard B, Ahern G, Cao P, Kolody H, Vedders L, Kolb WP, Sabbagh M.(2006) Peripheral clearance of amyloid beta peptide by complement C3-dependent adherence to erythrocytes. Neurobiol Aging 27, 1733-1739.

[35] Biere AL, Ostaszewski B, Stimson ER, Hyman BT, Maggio JE, Selkoe DJ (1996) Amyloid beta-peptide is transported on lipoproteins and albumin in human plasma. J Biol Chem 271, 32916-32922.

[36] Costa M, Ortiz AM, Jorquera JI (2012) Therapeutic albumin binding to remove amyloid-beta. J Alzheimers Dis 29, 159170.

[37] Kuo YM, Emmerling MR, Lampert HC, Hempelman SR, Kokjohn TA, Woods AS, Cotter RJ, Roher AE (1999) High levels of circulating Abeta42 are sequestered by plasma proteins in Alzheimer's disease. Biochem Biophys Res Commun 257, 787-791.

[38] Sagare AP, Deane R, Zetterberg H, Wallin A, Blennow $\mathrm{K}$, Zlokovic BV (2011) Impaired lipoprotein receptormediated peripheral binding of plasma amyloid-beta is an early biomarker for mild cognitive impairment preceding Alzheimer's disease. J Alzheimers Dis 24, 25-34.

[39] Kuo YM, Kokjohn TA, Kalback W, Luehrs D, Galasko DR, Chevallier N, Koo EH, Emmerling MR, Roher AE (2000) Amyloid-beta peptides interact with plasma proteins and erythrocytes: Implications for their quantitation in plasma. Biochem Biophys Res Commun 268, 750-756.

[40] Alegret M, Boada-Rovira M, Vinyes-Junque G, Valero S, Espinosa A, Hernandez I, Modinos G, Rosende-Roca M, Mauleon A, Becker JT, Tarraga L (2009) Detection of visuoperceptual deficits in preclinical and mild Alzheimer's disease. J Clin Exp Neuropsychol 31, 860-867.

[41] Alegret M, Espinosa A, Vinyes-Junque G, Valero S, Hernandez I, Tarraga L, Becker JT, Boada M (2012) Normative data of a brief neuropsychological battery for Spanish individuals older than 49. J Clin Exp Neuropsychol 34, 209-219.

[42] Scheltens P, Leys D, Barkhof F, Huglo D, Weinstein HC, Vermersch P, Kuiper M, Steinling M, Wolters EC, Valk J (1992) Atrophy of medial temporal lobes on MRI in "probable" Alzheimer's disease and normal ageing: Diagnostic value and neuropsychological correlates. J Neurol Neurosurg Psychiatry 55, 967-972.

[43] Hixson JE, Vernier DT (1990) Restriction isotyping of human apolipoprotein E by gene amplification and cleavage with HhaI. J Lipid Res 31, 545-548.

[44] Rissman RA, Trojanowski JQ, Shaw LM, Aisen PS (2012) Longitudinal plasma amyloid beta as a biomarker of Alzheimer's disease. J Neural Transm 119, 843-850.

[45] Lambert JC, Schraen-Maschke S, Richard F, Fievet N, Rouaud O, Berr C, Dartigues JF, Tzourio C, Alperovitch A, Buee L, Amouyel P (2009) Association of plasma amyloid beta with risk of dementia: The prospective Three-City Study. Neurology 73, 847-853.
[46] Lewczuk P, Kornhuber J, Vanmechelen E, Peters O, Heuser I, Maier W, Jessen F, Burger K, Hampel H, Frolich L, Henn F, Falkai P, Ruther E, Jahn H, Luckhaus C, Perneczky R, Schmidtke K, Schroder J, Kessler H, Pantel J, Gertz HJ, Vanderstichele H, De MG, Shapiro F, Wolf S, Bibl M, Wiltfang J (2010) Amyloid beta peptides in plasma in early diagnosis of Alzheimer's disease: A multicenter study with multiplexing. Exp Neurol 223, 366-370.

[47] Mattsson N, Portelius E, Rolstad S, Gustavsson M, Andreasson U, Stridsberg M, Wallin A, Blennow K, Zetterberg $\mathrm{H}$ (2012) Longitudinal cerebrospinal fluid biomarkers over four years in mild cognitive impairment. J Alzheimers Dis 29 , $1-12$.

[48] Okereke OI, Xia W, Selkoe DJ, Grodstein F (2009) Ten-year change in plasma amyloid beta levels and late-life cognitive decline. Arch Neurol 66, 1247-1253.

[49] Sagare A, Deane R, Bell RD, Johnson B, Hamm K, Pendu R, Marky A, Lenting PJ, Wu Z, Zarcone T, Goate A, Mayo K, Perlmutter D, Coma M, Zhong Z, Zlokovic BV (2007) Clearance of amyloid-beta by circulating lipoprotein receptors. Nat Med 13, 1029-1031.

[50] Slemmon JR, Meredith J, Guss V, Andreasson U, Andreasen N, Zetterberg H, Blennow K (2012) Measurement of Abeta $1-42$ in cerebrospinal fluid is influenced by matrix effects. $J$ Neurochem 120, 325-333.

[51] Sureshbabu N, Kirubagaran R, Jayakumar R (2009) Surfactant-induced conformational transition of amyloid beta-peptide. Eur Biophys J 38, 355-367.

[52] Matsubara E, Sekijima Y, Tokuda T, Urakami K, Amari M, Shizuka-Ikeda M, Tomidokoro Y, Ikeda M, Kawarabayashi T, Harigaya Y, Ikeda S, Murakami T, Abe K, Otomo E, Hirai S, Frangione B, Ghiso J, Shoji M (2004) Soluble Abeta homeostasis in AD and DS: Impairment of anti-amyloidogenic protection by lipoproteins. Neurobiol Aging 25, 833-841.

[53] Wolk DA, Price JC, Saxton JA, Snitz BE, James JA, Lopez OL, Aizenstein HJ, Cohen AD, Weissfeld LA, Mathis CA, Klunk WE, De-Kosky ST (2009) Amyloid imaging in mild cognitive impairment subtypes. Ann Neurol 65, 557-568.

[54] Lopez OL, Kuller LH, Becker JT, Ulberg C, Weet RA, Ach HM, EKosky ST (2007) Incidence of dementia in mild cognitive impairment in the cardiovascular health study cognition study. Arch Neurol 64, 416-420.

[55] Vemuri P, Wiste HJ, Weigand SD, Shaw LM, Trojanowski JQ, Weiner MW, Knopman DS, Petersen RC, Jack CR, Jr. (2009) MRI and CSF biomarkers in normal, MCI, and AD subjects: Predicting future clinical change. Neurology 73, 294301.

[56] Jagust WJ, Landau SM, Shaw LM, Trojanowski JQ, Koeppe RA, Reiman EM, Foster NL, Petersen RC, Weiner MW, Price JC, Mathis CA (2009) Relationships between biomarkers in aging and dementia. Neurology 73, 1193-1199.

[57] Landau SM, Harvey D, Madison CM, Koeppe RA, Reiman EM, Foster NL, Weiner MW, Jagust WJ (2009) Associations between cognitive, functional, and FDG-PET measures of decline in AD and MCI. Neurobiol Aging 32, 1287-1218.

[58] DeMeyer G, Shapiro F, Vanderstichele H, Vanmechelen E, Engelborghs S, De Deyn PP, Coart E, Hansson O, Minthon L, Zetterberg H, Blennow K, Shaw L, Trojanowski JQ (2010) Diagnosis-independent Alzheimer disease biomarker signature in cognitively normal elderly people. Arch Neurol 67, 949-956.

[59] Jack CR, Jr., Vemuri P, Wiste HJ, Weigand SD, Lesnick TG, Lowe V, Kantarci K, Bernstein MA, Senjem ML, Gunter JL, Boeve BF, Trojanowski JQ, Shaw LM, Aisen PS, Weiner MW, Petersen RC, Knopman DS (2012) Shapes of the trajectories 
of 5 major biomarkers of Alzheimer disease. Arch Neurol 69, 856-867.

[60] Devanand DP, Schupf N, Stern Y, Parsey R, Pelton GH, Mehta P, Mayeux R (2011) Plasma Abeta and PET PiB binding are inversely related in mild cognitive impairment. Neurology $\mathbf{7 7}$, 125-131.

[61] Figurski MJ, Waligorska T, Toledo. J, Vanderstichele H, Korecka M, Lee VM, Trojanowski JQ, Shaw LM (2012) Improved protocol for measurement of plasma betaamyloid in longitudinal evaluation of Alzheimer's Disease
Neuroimaging Initiative study patients. Alzheimers Dement 8, 250-260.

[62] Bateman RJ, Xiong C, Benzinger TL, Fagan AM, Goate A, Fox NC, Marcus DS, Cairns NJ, Xie X, Blazey TM, Holtzman DM, Santacruz A, Buckles V, Oliver A, Moulder K, Aisen PS, Ghetti B, Klunk WE, McDade E, Martins RN, Masters CL, Mayeux R, Ringman JM, Rossor MN, Schofield PR, Sperling RA, Salloway S, Morris JC (2012) Clinical and biomarker changes in Dominantly Inherited Alzheimer's Disease. NEngl J Med 367, 795-804. 